\section{Cytological Analysis of a Clethra alnifolia 'Hokie Pink' $\times$ C. pringlei Hybrid}

\author{
Sandra M. Reed ${ }^{1}$
}

Floral and Nursery Plants Research Unit, U.S. National Arboretum, Agricultural Research Service, U.S. Department of Agriculture, Tennessee State University Otis L. Floyd Nursery Research Center, 472 Cadillac Lane, McMinnville, TN 37110

Additional index words. summersweet, breeding, interspecific hybridization, unreduced gamete, tetraploidy

\begin{abstract}
Clethra alnifolia L., a native deciduous shrub cultivated as an ornamental, was recently hybridized with $C$. pringlei $\mathrm{S}$. Wats. The purpose of this hybridization was to combine the cold hardiness and adaptability of $C$. alnifolia with the ornamental foliage of $C$. pringlei. While most of the $C$. alnifolia $\times C$. pringlei hybrids more closely resembled $C$. alnifolia than the paternal species, a 'Hokie Pink' $\times C$. pringlei hybrid (NA71586) with foliage that flushes red like $C$. pringlei was recovered. The objectives of this study were to analyze cytologically the $F_{1}$ and produce a $F_{2}$ population from NA71586. Chromosome counts from root tips cells indicated that NA71586 has 32 chromosomes. Since the chromosome number of $C$. alnifolia is $2 \mathrm{n}=32$ and that of $C$. pringlei was found to be $2 \mathrm{n}$ $=16$, NA71586 appears to have developed following fertilization of a $C$. alnifolia egg with an unreduced male gamete from $C$. pringlei. Both 'Hokie Pink' and $C$. pringlei exhibited primarily bivalent pairing in pollen mother cells (PMCs). Over half of the PMCs from NA71586 contained 16 bivalents, indicating substantial homology within the $C$. alnifolia genome. It was theorized that $C$. alnifolia is either an autotetraploid that exhibits bivalent pairing or a segmental allotetraploid produced from hybridization of species with similar genomes. More than $700 \mathrm{~F}_{2}$ progeny were obtained from self-pollination of NA71586. Although many of the $F_{2}$ progeny resembled NA71586, variation in foliage color, size and shape was apparent in the population.
\end{abstract}

The genus Clethra, which is the sole member of Clethraceae, consists of approximately 70 species of deciduous and evergreen shrubs and small trees (Sleumer, 1967a, 1967b; Hamilton, 1985). The genus is divided into two sections based primarily on geographic distribution and seed characteristics (Sleumer, 1967a). The 25 members of Section Clethra are native to eastern U.S. and eastern Asia, whereas sect. Cuellaria species are found in Mexico, Central and South America, and Madeira. Several Clethra species are cultivated as ornamentals, but the most widely grown member of the genus in the U.S. is C. alnifolia. Commonly known as sweet pepper bush or summersweet, this deciduous shrub is found in acid swamps and low, moist woods along the Coastal Plain from Maine to Louisiana (Wilbur and Hespenheide, 1967). It is valued for its dark green pest-resistant foliage, attractive racemes or panicles of fragrant white or pink flowers, and ability to grow under a wide range of environmental conditions. The species is rated hardy in USDA Hardiness Zones 4 to 9 (Dirr, 1998).

Clethra alnifolia was recently hybridized to C. pringlei (Reed, 2001; Reed et al., 2002),

Received for publication 29Dec. 2003. Accepted for publication 8 Mar. 2004. Mention of trade names of commercial products in the publication is solely for the purpose of providing specific information and does not imply recommendation or endorsement by the U.S. Department of Agriculture.

${ }^{1}$ Research geneticist. To whom reprint requests should be addressed; e-mail sreed@blomand.net. which is a Mexican species with glossy, evergreen foliage that flushes a deep reddishbronze. Because $C$. pringlei is hardy only to USDA Hardiness Zone 8, it is not commonly used as an ornamental in the U.S. The goal of this hybridization was to combine cold hardiness and adaptability from $C$. alnifolia with the attractive foliage characteristics of $C$. pringlei. Pollinations made in 1998 resulted in one 'Fern Valley Pink' $\times$ C. pringlei and 11 'Ruby Spice' $\times$ C. pringlei hybrids (Reed et al., 2002). Comparisons of morphological characteristics and RAPD banding patterns between hybrids and parental species indicated that the hybrids more closely resembled their $C$. alnifolia parent than $C$. pringlei; however, individual plants exhibited one or more morphological characteristics from the paternal parent. No plant with the desired foliage characteristics was obtained from $\mathrm{F}_{2}$ populations derived from intercrossing 'Ruby Spice' $\times$ C. pringlei hybrids (S.M. Reed, unpublished data.)

Pollinations made between C. alnifolia and C. pringlei in 1999 resulted in 19 additional progeny (Reed, 2001). The 17 plants obtained from crosses involving C. alnifolia 'Hummingbird' or 'Ruby Spice' as the maternal parent were similar in appearance to hybrids obtained the previous year. In contrast, two progeny obtained from 'Hokie Pink' $\times C$. pringlei pollinations much more strongly resembled $C$. pringlei than did the other $C$. alnifolia $\times C$. pringlei hybrids. Many of the characteristics of these hybrids were either intermediate to the parents or similar to those of $C$. pringlei (Table 1). While the new foliage of both 'Hokie Pink' $\times C$. pringlei hybrids was distinctly redder than that of 'Hokie Pink' or other C. alnifolia cultivars, the foliage of one hybrid was much more intensely colored than that of the other. This hybrid, which was previously referred to as 402A (Reed, 2001), was assigned U.S. National Arboretum accession number NA71586. Growth and ornamental characteristics of NA71586 are currently being evaluated in U.S. nurseries at various locations within the $C$. alnifolia production range. Regardless of its commercial merit, NA71586 potentially represents a valuable source of germplasm for use in a Clethra breeding program. The objectives of this study were to cytologically analyze and produce $\mathrm{F}_{2}$ progeny from NA71586.

\section{Materials and Methods}

Plant materials. Clethra alnifolia 'Hokie Pink', C. pringlei, and C. alnifolia 'Hokie Pink' $\times$ C. pringlei NA71586 were grown in 56.8 -L containers in full sun and microirrigated using spray stakes. Growing medium consisted of pine bark amended with 6.6 $\mathrm{kg} \cdot \mathrm{m}^{-3} 19 \mathrm{~N}-2.1 \mathrm{P}-7.4 \mathrm{~K}$ Osmocote Pro fertilizer (Scotts-Sierra Horticultural Products Co., Maryville, Ohio), $0.6 \mathrm{~kg} \cdot \mathrm{m}^{-3}$ Micromax (Scotts-Sierra Horticultural Products Co.), 0.6 $\mathrm{kg} \cdot \mathrm{m}^{-3}$ iron sulfate, and $0.2 \mathrm{~kg} \cdot \mathrm{m}^{-3}$ Epsom salts. Cuttings of NA71586 were dipped for $5 \mathrm{~s}$ in $4.9 \mathrm{~mm}$ indole-3-butyric acid in 50\% ethanol, stuck into 1 peat : 1 perlite (by volume), and placed under mist. When roots developed, cuttings were moved to square $(12.7-\mathrm{cm})$ plastic containers containing the pine bark growing medium described above. Rooted cuttings were kept in the greenhouse under drip irrigation until root tips were collected.

Mitotic chromosome counts. Root tips were collected from rooted cuttings of NA71586 and placed in $1.2 \mathrm{~mm}$ colchicine for $3 \mathrm{~h}$ at room temperature, then transferred to Carnoy's fixative (3:1 95\% ethanol : glacial acetic acid) for $24 \mathrm{~h}$, and stored in $70 \%$ ethanol at $5{ }^{\circ} \mathrm{C}$ for up to 1 week. Root tips were hydrolyzed for $5 \mathrm{~min}$ in $5 \mathrm{~N} \mathrm{HCl}$ at room temperature (21 to $22{ }^{\circ} \mathrm{C}$ ), rinsed in distilled water, and soaked in $1 \%$ acetocarmine for $30 \mathrm{~min}$. The meristematic region of the root tip was squashed in acetocarmine and chromosomes counted in ten metaphase cells.

Meiotic analysis. Chromosome pairing was studied in pollen mother cells (PMCs) of NA71586 and its parents. Panicles about 3 to 7 $\mathrm{cm}$ in length were collected, fixed in Carnoy's fixative at room temperature for $24 \mathrm{~h}$, then transferred to $70 \%$ ethanol and stored at $5{ }^{\circ} \mathrm{C}$ for up to 3 months. Anthers were squashed in 1\% acetocarmine. Chromosome pairing was determined from cells at diakinesis or metaphase I. Number of lagging chromosomes was recorded in anaphase I, metaphase II, and anaphase II cells. At least 25 cells were analyzed for each meiotic stage examined.

Pollen staining. Three flowers were collected from each taxa on the day of anthesis. Three anthers from each flower were placed on a microscope slide and squashed in a drop 


\begin{tabular}{|c|c|c|c|c|}
\hline \multirow[b]{3}{*}{ Characteristic } & \multicolumn{4}{|c|}{ Taxa } \\
\hline & \multirow[b]{2}{*}{ Hokie Pink } & \multirow[b]{2}{*}{ C. pringlei } & \multicolumn{2}{|c|}{ Hokie Pink $\times C$. pringlei } \\
\hline & & & Plant 1 (NA71586) & Plant 2 \\
\hline Red pigmentation in new foliage & No & Yes & Yes & Yes \\
\hline Fall foliage color & Yellow & Green until killed by & Green until killed by & Green until killed by \\
\hline & & low temperatures & low temperatures & low temperatures \\
\hline Flower color & Medium pink & White & Very pale pink & White \\
\hline Inflorescence form & Upright panicle & Very drooping panicle & Moderately drooping panicle & Moderately drooping panicle \\
\hline Leaf length $(\mathrm{cm})^{\mathrm{z}}$ & $6.4 \mathrm{c}$ & $9.3 \mathrm{a}$ & $8.7 \mathrm{ab}$ & $8.1 \mathrm{~b}$ \\
\hline Leaf width (cm) & $2.8 \mathrm{c}$ & $4.6 \mathrm{a}$ & $4.6 \mathrm{a}$ & $3.6 \mathrm{~b}$ \\
\hline Leaf length:width & $2.3 \mathrm{a}$ & $2.0 \mathrm{bc}$ & $1.9 \mathrm{c}$ & $2.2 \mathrm{ab}$ \\
\hline Petiole length (mm) & $4.9 \mathrm{a}$ & $2.4 \mathrm{c}$ & $2.0 \mathrm{c}$ & $3.6 \mathrm{~b}$ \\
\hline
\end{tabular}

${ }^{2}$ Leaf measurement data from Reed, 2001. Mean separation by Fisher's LSD test $(P \leq 0.05)$.

of $1 \%$ acetocarmine stain. Specimens were examined using a light microscope and pollen scored as stained or unstained. Three fields of 100 grains each were counted and a mean number of stained grains calculated for each slide. Fisher's LSD test was used to compare percent stainable pollen among taxa.

Production of $F_{2}$ progeny. NA71586 was self-pollinated during summer 2002. Inflorescences were covered with breathable plastic bags (DelStarTechnologies, Middletown, Del.) before flower opening. Bags were removed from inflorescences and pollen collected by holding open flowers over a $30-\mathrm{cm}$ plastic petri dish and tapping each flower with a pair of forceps. After pollen was collected from all open flowers, it was applied to stigmas of the same group of flowers using a fine-tipped brush. Self-pollinations were made every second day from the time the first flower opened until flowering was complete. Bags remained over the inflorescences until 2 weeks after the last pollination was made.

Seed capsules were collected in late October, placed in paper bags and kept at room temperature $\left(21\right.$ to $\left.22^{\circ} \mathrm{C}\right)$ until completely dry. Capsules were crushed and seeds separated from debris using a stereomicroscope. Seeds were stored in glassine bags at $5{ }^{\circ} \mathrm{C}$ for 2 months before sowing on the surface of a commercial seed propagation mix (Grow Mix \#1, Morton's Horticultural Products, Inc., McMinnville, Tenn.) in shallow (3-cm) seedling flats. Seed trays were placed in a heated greenhouse under mist. Bottom heat was provided during germination. Seedlings were transplanted to individual $5.7 \times 4.9 \mathrm{~cm}$ cell packs containing Pro Mix BX (Premier Horticulture, Quakertown, $\mathrm{Pa}$.) when the second set of true leaves had developed. Seedlings were later transplanted to square $12.7 \mathrm{~cm}$ pots and then to 11.4-L containers using the pine bark media described above. Plants that were very small or that had heavily variegated foliage were kept in the greenhouse under $60 \%$ shade, but the remainder of the plants were grown on a gravel lined bed in full sun. In October 2003, general observations on plant phenotype were recorded and plant height measured.

\section{Results}

Cytological analysis and pollen staining. Root tip cells of NA71586 contained 32 chromosomes (Fig. 1A). Up to 6 univalents were observed at diakinesis or metaphase I
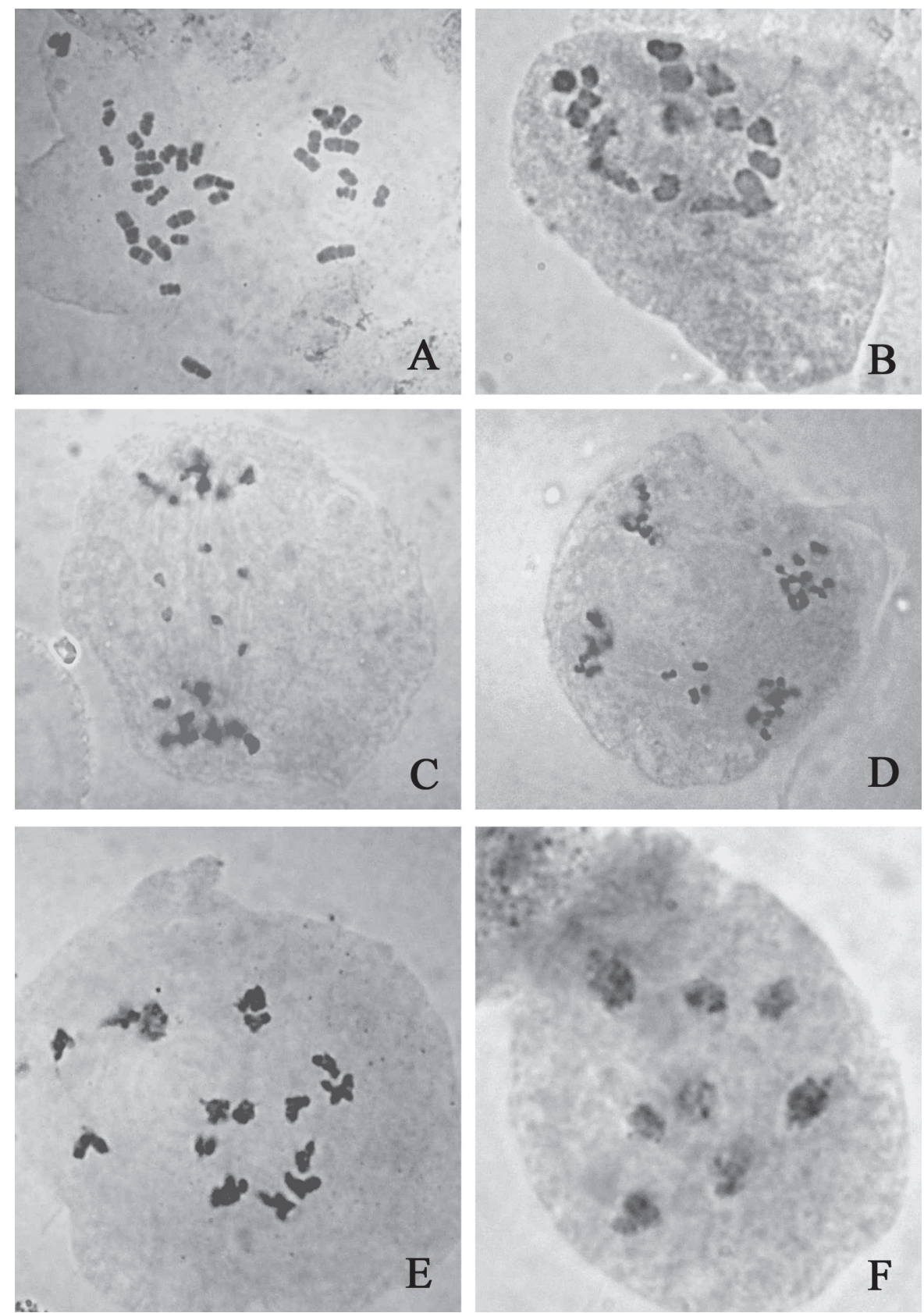

Fig. 1. Photomicrographs of Clethra alnifolia 'Hokie Pink' $\times$ C. pringlei hybrid NA71586, 'Hokie Pink', and $C$. pringlei. (A) NA71586 root tip cell with 32 chromosomes, (B) NA71586 pollen mother cell (PMC) with 16 bivalents, (C) NA71586 anaphase I PMC with six lagging chromosomes, (D) NA71586 anaphase II PMC with group of four lagging chromosomes, (E) 'Hokie Pink' PMC with 16 bivalents, (F) C. pringlei $\mathrm{PMC}$ with 8 bivalents.

in NA71586, but $60 \%$ of the cells contained 16 bivalents (Table 2, Fig. 1B). Lagging

chromosomes were observed in $29 \%$ to $53 \%$ of the PMCs observed at later meiotic stages 
(Fig. 1C-D), with a maximum of eight lagging chromosomes recorded at anaphase I. Mean number of lagging chromosomes ranged from 0.7 at anaphase II to 1.0 at anaphase I. Slightly more than one-fourth of the pollen grains of NA71586 were classified as stained.

Both 'Hokie Pink' and C. pringlei exhibited primarily bivalent pairing at diakinesis and metaphase I (Fig. 1E-F). No multivalents were observed in PMCs of either taxa, but $8 \%$ of the 'Hokie Pink' cells contained one or more unpaired chromosomes. A few cells with one to two lagging chromosomes were observed in metaphase and anaphase II cells of 'Hokie Pink', but no lagging chromosomes were observed in $C$. pringlei. Both parental taxa produced over $90 \%$ stainable pollen.

Production of $F$, progeny. Self-pollination of about 500 NA71586 flowers yielded 900 to 1000 seed, 701 of which germinated. While several were slow-growing, $624 \mathrm{~F}_{2}$ plants were alive at the end of the 2003 growing season. Plant height at the end of the first growing season for the entire $F_{2}$ population ranged from 3 to $136 \mathrm{~cm}$, with a mean of $48.5 \mathrm{~cm}$. Although many of the $F_{2}$ progeny resembled NA71586, variation in foliage color, size and shape was observed in the population. Almost $8 \%$ of the population had variegated foliage, while another $12 \%$ had leaves that were reduced to about one-fourth the length and width of those of other individuals in this population. One plant with abnormally small leaves and variegated foliage was observed.

The most striking feature of this population was observed among the $472 \mathrm{~F}_{2}$ plants that were grown outdoors, which included 4 variegated and 24 small-leafed individuals. When the first killing freeze $\left(-4.2^{\circ} \mathrm{C}\right)$ was observed on 13 Nov. 2003, the foliage of all $F_{2}$ progeny remained green and intact on the plant. While some plants experienced leaf damage following this freeze, especially to new foliage, no visible damage was apparent on most leaves. The foliage of NA71586 behaved in a similar manner. As a comparison, leaves of C. alnifolia plants grown in the same area turned yellow in October and had almost completely abscised by the time of the first freeze.

\section{Discussion}

Observations of 16 bivalents in PMCs of 'Hokie Pink' agreed with the previously reported chromosome number of $2 n=32$ for C. alnifolia (Hagerup, 1928; Tanaka and Oginuma, 1980). The presence of 8 bivalents in $C$. pringlei indicates that this species has 16 somatic chromosomes, which is the first reported chromosome number for this species. Two other Clethra species have been reported to have a chromosome number of $2 n$ $=16$ (Hagerup, 1928; Kyhos, 1965). Like $C$. pringlei, both of these species are members of sect. Cuellaria (Sleumer, 1967b).

Based on the chromosome numbers of the parental species, hybridization between C. alnifolia and $C$. pringlei was expected to produce progeny with 24 somatic chromosomes. However, root tip cells 'Hokie Pink' $\times C$. pringlei hybrid NA71586 contained 32 chromosomes. It appears that NA71586 resulted from the fusion of an egg cell from 'Hokie Pink' with an unreduced male gamete from $C$. pringlei. Sixteen of the chromosomes in NA71586 represent one set of $C$. alnifolia chromosomes, while the other 16 represent two complete sets of $C$. pringlei chromosomes. Over half of the metaphase IPMCs exhibited 16 bivalents, indicating pairing not only between the homologous $C$. pringlei chromosomes but also between $C$. alnifolia chromosomes.

Tanaka and Oginuma (1980) proposed that the basic chromosome number in Clethra is $\mathrm{x}=8$. This theory was based on the presence of $2 \mathrm{n}=16$ chromosomes in $C$. arborea Ait. and $C$. lanata Martens \& Gal., of $2 \mathrm{n}=80$ chromosomes in C. barbinervis Sieb. \& Zucc., and by karyotype analysis in which four long metacentric chromosomes were observed in
C. alnifolia and ten similar chromosomes were found in $C$. barbinervis. While they classified C. alnifolia as a tetraploid, they did not speculate as to whether it was of auto- or allopolyploid origin.

Autopolyploids result from chromosome doubling of genetically identical genomes and often produce multivalents at meiosis. Allopolyploids arise from interspecific hybridization followed by chromosome doubling. Stebbins (1950) distinguished between genomic and segmental allopolyploids based on the amount of similarity between the genomes of the parental species. Genomic allopolyploids are derived from species with fully differentiated chromosomes and exhibit bivalent pairing. Segmental allopolyploids result from hybridization between species that have only partially differentiated chromosomes. Preferential pairing in segmental allopolyploids is expected to result in primarily bivalent pairing, but multivalents may occasionally be formed.

Based on the high degree of bivalent pairing within the single set of 'Hokie Pink' chromosomes present in NA71586, there appears to be considerable homology between the two genomes in C. alnifolia. This indicates that this species is an autotetraploid or a segmental allotetraploid. Lack of multivalents in 'Hokie Pink' adds support for a segmental allotetraploid origin, but does not rule out autotetraploidy since some autopolyploids, such as alfalfa (Bingham and McCoy, 1988), exhibit bivalent pairing. Cytological evaluation of a wider range of C. alnifolia germplasm is needed to develop a more complete understanding of the origin of this species.

Assuming that none of the bivalents that were observed in NA71586 represented pairing between $C$. alnifolia and $C$. pringlei chromosomes, there appears to be little possibility of genetic recombination occurring between the genomes of the two species in this intersectional hybrid. Based on the high frequency of bivalent

Table 2. Percent stainable pollen, chromosome pairing configurations, and lagging chromosomes in Clethra alnifolia 'Hokie Pink', C. pringlei and their hybrid.

\begin{tabular}{|c|c|c|c|c|c|c|}
\hline Plant & $\begin{array}{l}\text { Stainable } \\
\text { pollen } \\
(\%)^{z}\end{array}$ & $\begin{array}{l}\text { Meiotic } \\
\text { stage }\end{array}$ & $\begin{array}{l}\text { Cells } \\
\text { observed } \\
\text { (no.) }\end{array}$ & Configuration ${ }^{y}$ & $\begin{array}{l}\text { Cells with } \\
\text { lagging } \\
\text { chromosomes } \\
\text { (no.) }\end{array}$ & $\begin{array}{l}\text { Lagging } \\
\text { chromosomes } \\
\text { per PMC, } \\
\text { mean (range) } \\
\text { (no.) }\end{array}$ \\
\hline \multirow[t]{5}{*}{ Hokie Pink } & $90.5 \mathrm{a}$ & Diakinesis/metaphase I & 23 & $16 \mathrm{II}$ & & \\
\hline & & & 2 & $15 \mathrm{II}+2 \mathrm{I}$ & & \\
\hline & & Anaphase I & 26 & & 0 & --- \\
\hline & & Metaphase II & 26 & & 3 & $0.1(0-1)$ \\
\hline & & Anaphase II & 32 & & 1 & $0.1(0-2)$ \\
\hline \multirow[t]{4}{*}{ C. pringlei } & $90.8 \mathrm{a}$ & Diakinesis/metaphase I & 25 & $8 \mathrm{II}$ & & \\
\hline & & Anaphase I/telophase I & 34 & & 0 & --- \\
\hline & & Metaphase II & 27 & & 0 & --- \\
\hline & & Anaphase II & 28 & & 0 & --- \\
\hline \multirow[t]{8}{*}{ Hokie Pink $\times C$. pringlei (NA71586) } & $26.2 \mathrm{~b}$ & & & & & \\
\hline & & Diakinesis/metaphase I & 15 & $16 \mathrm{II}$ & & \\
\hline & & & 7 & $15 \mathrm{II}+2 \mathrm{I}$ & & \\
\hline & & & 2 & $14 \mathrm{II}+4 \mathrm{I}$ & & \\
\hline & & & 1 & $13 \mathrm{II}+6 \mathrm{I}$ & & \\
\hline & & Anaphase I & 53 & & 20 & $1.0(0-8)$ \\
\hline & & Metaphase II & 40 & & 16 & $0.9(0-6)$ \\
\hline & & Anaphase II & 29 & & 7 & $0.7(0-6)$ \\
\hline
\end{tabular}

${ }^{2}$ Mean separation by Fisher's $t$ test, $P \leq 0.05$.

${ }^{y} \mathrm{II}=$ bivalent, $\mathrm{I}=$ univalent. 
formation in NA71586 and the phenotypic similarity between the $F_{1}$ and many $F_{2}$ plants, many of the $\mathrm{F}_{2}$ plants are expected to have the same complement of chromosomes as the $F_{1}$. The presence of univalents and lagging chromosomes in PMCs of NA71586 should have resulted in gametes with different chromosome complements; however, since only about onefourth of the pollen grains of NA71586 appeared viable, many of these gametes may not have participated in fertilization. Cytological analysis of the NA71586 $\mathrm{F}_{2}$ progeny is needed to determine if the phenotypic variation that was found in this population is due strictly to gene segregation or if aneuploid differences in chromosome number are responsible for some of the variability. Continued evaluation of cold hardiness, adaptability and ornamental characteristics of $\mathrm{F}_{2}$ progeny are needed to determine if plants with the desired combina- tion of parental traits can be obtained without recombination between parental genomes. Fortunately, because $C$. alnifolia culivars are vegetatively propagated, interesting and useful variants from $\mathrm{F}_{2}$ and other advanced populations can be maintained and utilized even in the absence of sexual transmission of the entire chromosome complement.

\section{Literature Cited}

Bingham, E.T. and T.J. McCoy. 1988. Cytology and cytogenetics of alfalfa, p. 737-776. In: A.A. Hanson (ed.). Alfalfa and alfalfa improvement. ASA-CSSA-SSSA Agron. Monogr. 29.

Dirr, M.A. 1998. Manual of woody landscape plants. Stipes Publ., Champaign, Ill.

Hagerup, O. 1928. Morphological and cytological studies of Bicornes. Dansk. Bot. Ark. 6:27.

Hamilton, C.W. 1985. Notes on and descriptions of seven new species of Mesoamerican Clethraceae.
Ann. Mo. Bot. Gard. 72:539-543.

Kyhos, D.W. 1965. Documented chromosome numbers of plants. Madrono 18:122-126.

Reed. S. M. 2001. Hybridization of Clethra alnifolia and $C$. pringlei. Proc. S. Nursery Assn. Res. Conf. 46:407-410.

Reed, S. M., Y. Joung, and M. Roh. 2002. Interspecific hybridization in Clethra. HortScience 37:393-397.

Sleumer, H. 1967a. Monographia Clethracearum. Part I. Bot. Jahrb. Syst. 87:36-116.

Sleumer, H. 1967b. Monographia Clethracearum. Part. II. Bot. Jahrb. Syst. 87:117-175.

Stebbins, Jr., G.L. 1950. Variation and evolution in plants. Columbia Univ. Press, New York.

Tanaka, R. and K. Oginuma. 1980. Karyomorphological studies on Clethra barbinervis and two allied species. J. Jpn. Bot. 55:65-72.

Wilbur, R.L. and H.A. Hespenheide. 1967. The genus Clethra (Clethraceae) in the United States. J. Elisa Mitchell Soc. 83:82-88. 